\title{
PROSES ULTRAFILTRASI UNTUK PENJERNIHAN SARI BUAH MARKISA (Passiflora quadrangularis) DENGAN MEMANFAATKAN MEMBRAN KERAMIK
}

\author{
Refinel, Olly Norita Tetra, Roza Melia Usmita \\ Laboratorium Kimia Fisika, Jurusan Kimia FMIPA, Universitas Andalas \\ Jurusan Kimia FMIPA Unand, Kampus Limau Manis, 25163 \\ e-mail: nafirefinel21@yahoo.com
}

\begin{abstract}
Ultrafiltration of passion fruit juice using variation thickness of ceramic membrane has been done. The result shows that aquades flux value in 25 minutes for membrane $1.5 ; 2.0 ; 2.5 ; 3.0$; and $3.5 \mathrm{~mm}$ is $17.0135 ; 19.1947 ; 10.9061 ; 10.9061$ and $4.3624 \mathrm{~L} / \mathrm{h} \mathrm{m}^{2}$. Whereas passion fruit juice in same time for membrane $1.5 ; 2.0 ; 2.5 \mathrm{~mm}$ is $8.2886 ; 5.6712$ and $4.3624 \mathrm{~L} / \mathrm{h} \mathrm{m}^{2}$. For membrane 3.0 and $3.5 \mathrm{~mm}$ it has not been done because flux value are too small that indicate fouling. Physical and chemical properties parameter in ultrafiltration of passion fruit juice obtained for turbidity and color very different between passion fruit juice before and after ultrafiltration, whereas reducing sugar and vitamin $\mathrm{C}$ are not significant different between passion fruit juice before and after ultrafiltration. Determination rejection coefficient value of membrane for turbidity, color relatively significant whereas for reducing sugar and vitamin $\mathrm{C}$ are relatively not significant.
\end{abstract}

Keywords: Membrane Technology, Ceramic Membrane, Fouling, Passion Fruit, Reducing Sugar, Vitamin C.

\section{PENDAHULUAN}

Ultrafiltrasi sebagai suatu metoda penyaringan dengan menggunakan membran banyak digunakan pada saat ini. Ultrafiltrasi adalah suatu proses filtrasi melalui membran ukuran porinya berkisar antara $0,001-0,02$ $\mu \mathrm{m}$. Metode ini umumnya digunakan untuk memisahkan koloid, mengurangi konsentrasi, pemurnian dan fraksionasi makromolekul seperti protein, zat warna dan bahan-bahan polimerik lainnya ${ }^{[1]}$.

Pada industri kegunaan dari teknologi membran adalah untuk menggantikan langkah pemisahan dan pemurnian yang akan mengurangi konsumsi energi dan menghasilkan produk yang diinginkan. Dibandingkan dengan membran organik, membran anorganik menawarkan beberapa keuntungan yaitu sifat termal yang baik, ketahanan kimia, dan sifat mekanik yang baik.

Aplikasi dari penggunaan ultrafiltrasi di industri adalah untuk meningkatkan fraksi protein susu keju atau beberapa produk lain yang berguna dan mengurangi limbah dilakukan oleh Saxena (2009), dilaporkan bahwa membran ultrafiltrasi yang digunakan memiliki kinerja yang baik dalam berbagai penggunaannya. Belakangan ini ultrafiltrasi banyak digunakan untuk bio-makromolekul, termasuk protein seperti terapi rekombinan dan enzim industri ${ }^{[2]}$.

Membran yang digunakan pada penelitian ini yaitu membran keramik yang berasal dari keramik lantai. Teknologi pemisahan dengan menggunakan membran memiliki beberapa keunggulan yaitu pemisahan dapat dilakukan secara kontinu, sederhana, tidak membutuhkan zat kimia tambahan,dan juga kebutuhan energinya sangat minimum yang 
digunakan untuk penyaringan dari sari buah apel ${ }^{[3]}$.

Teknologi membran dengan menggunakan metode ultrafiltrasi memiliki prospek yang baik pada pengolahan limbah diantaranya adalah untuk pengolahan limbah cair berminyak yang dilakukan di Semarang. Ultrafiltrasi juga memiliki kinerja yang baik untuk menjernihkan jus pada buah dan sayuran. Selain itu, ultrafiltrasi telah digunakan dalam hubungannya dengan pertukaran ion resin untuk menjernihkan jus markisa dan untuk debit jus jeruk ${ }^{[4.5]}$.

Buah markisa memiliki banyak manfaat bagi kesehatan karena memiliki kandungan nutrisi yang berkhasiat. Adapun manfaat yang terkandung di dalam buah markisa adalah sebagai antioksidan yang mampu menghambat pertumbuhan sel - sel kanker di dalam tubuh manusia. Penelitian ilmiah yang mengkaji manfaat markisa menunjukkan bahwa markisa bermanfaat terhadap penurunan kolesterol karena kandungan seratnya yang cukup tinggi yaitu mengandung serat diet sekitar 10,40 g atau $27 \%$ dari massa buahnya ${ }^{[6]}$.

Solok adalah sebagai salah satu daerah pemasok buah markisa (Passiflora quadrangularis). Buah ini indentik mempunyai rasa masam sehingga jarang dimanfaatkan secara langsung dan hanya dibuat sebagai bahan minuman. Disamping itu, buah ini sedikit pemanfaatannya karena memiliki biji yang banyak sehingga masih minimnya yang mengolah markisa tersebut sebagai minuman.

Berdasarkan latar belakang di atas, akan dilakukan penelitian terhadap buah markisa yang memiliki kandungan biji yang banyak. Penelitian ini menggunakan membran keramik dari keramik lantai. Adapun ukuran ketebalan dari membran ini akan divariasikan untuk memisahkan larutan sari buah markisa dari koloidnya melalui metode ultrafiltrasi. Membran keramik yang dibutuhkan pada penelitian ini sangat mudah didapatkan yaitu dari keramik yang dijual di pasaran. Sari buah markisa yang telah didaptkan selanjutnya di filtrasi dan diuji kadar gula, vitamin $\mathrm{C}$, warna dan kekeruhan, hasil ini kemudian dibandingkan sari buah sebelum dan sesudah ultrafiltrasi.

\section{METODOLOGI PENELITIAN}

\section{Bahan}

Bahan-bahan yang digunakan adalah buah markisa dari Solok, $\mathrm{CuSO}_{4} \cdot 5 \mathrm{H}_{2} \mathrm{O}$ (tembaga(II) sulfat pentahidrat), $\mathrm{C}_{6} \mathrm{H}_{8} \mathrm{O}_{7}$ (asam sitrat), $\mathrm{Na}_{2} \mathrm{CO}_{3}$ (natrium karbonat), $\mathrm{N}_{2} \mathrm{~S}_{2} \mathrm{O}_{3}$, KI (kalium iodida), $\mathrm{H}_{2} \mathrm{SO}_{4} 98 \%$ (asam sulfat), $\mathrm{Na}_{2} \mathrm{HPO}_{4}$ (natrium hidrogen pospat), $\mathrm{HCl} 37 \%$ (asam klorida), akuades, Larutan kanji, $\mathrm{Na}_{2} \mathrm{~S}_{2} \mathrm{O}_{3}$ (natrium tiosulfat).

\begin{abstract}
Alat
Alat yang digunakan dalam penelitian ini adalah satu set alat ultrafiltrasi, timbangan, peralatan gelas, alumunium voil, corong, kertas saring, sentrifuge, buret, hotplate stirrer, pompa Air, spektrofotometer UV-vis (51000 SECOMAM), Portable Turbidimeter (Orbeco-Hellige Infrared).
\end{abstract}

\section{Preparasi Membran Keramik Pengamatan}

Membran keramik yang digunakan diperoleh dari keramik lantai yang ada di pasaran dengan merk prince. Bagian keramik yang diambil hanya bagian dalamnya saja sedangkan bagian yang licinnya dibuang. Membran keramik ini dibentuk seperti lingkaran berdiameter lebih kurang $5 \mathrm{~cm}$ dengan menggunakan alat pemotong keramik kemudian ditipiskan dengan menggunakan batu asahan dan dibuat variasi ketebalannya 1,$5 ; 2 ; 2,5 ; 3 ; 3,5 \mathrm{~mm}$.

\section{Preparasi Sari Buah Markisa}

Buah markisa dibeli di Solok, dibuka kulitnya kemudian ditimbang seberat $25 \mathrm{~g}$. Selanjutnya dimasukkan ke dalam blender dengan $100 \mathrm{~mL}$ aquadest untuk menghancurkan buah markisa selama 2 menit. Setelah 2 menit dimatikan blender dan diencerkan dalam labu $1000 \mathrm{~mL}$. Sari buah markisa disaring dengan kain kasa. Kemudian difiltrasi dengan membran keramik yang telah disiapkan menggunakan metoda ultrafiltrasi.

\section{Penentuan Fluks Akuades pada Membran}

Alat ultrafiltrasi disiapkan dan dipasangkan selang yang menghubungkan antara vacum dengan erlenmeyer penampung permeat. 
Akuades dimasukkan kedalam pipa penampung, kemudian dihidupkan mesin vacum dan dimulai proses filtrasi. Pengukuran fluks dilakukan dengan menampung volume permeat yang dihasilkan, dicatat volume setiap 5 menit selama 25 menit.

\section{Penentuan Fluks Sari Buah Markisa pada Membran}

Alat ultrafiltrasi disiapkan dan dipasangkan selang yang menghubungkan antara vacum dengan erlenmeyer penampung filtrat. Sari buah dimasukkan kedalam pipa penampung, kemudian dihidupkan mesin vacum dan dimulai proses filtrasi. Pengukuran fluks dilakukan dengan menampung volume permeat yang dihasilkan, dicatat volume setiap 5 menit selama 25 menit. Setiap sari buah yang melewati membran diberi kode, sebagai berikut :

S0 = Sari buah markisa setelah disaring tanpa filtrasi

$\mathrm{S} 1,5=$ Sari buah markisa melewati membran $1,5 \mathrm{~mm}$

$\mathrm{S} 2,0=$ Sari buah markisa melewati membran 2,0 $\mathrm{mm}$

$\mathrm{S} 2,5=$ Sari buah markisa melewat membran $2,5 \mathrm{~mm}$

\section{Penentuan Nilai Kekeruhan Sari Buah Markisa}

Sari buah dipipet $10 \mathrm{~mL}$ diencerkan dalam labu $50 \mathrm{~mL}$ kemudian diukur kekeruhannya. Penentuan nilai kekeruhan dilakukan pada sari buah sebelum dan sesudah melewati membran diukur dengan alat turbidimeter di laboratorium kesehatan.

\section{Pengukuran Spektrum Serapan Sari Buah Markisa}

Pengukuran spektrum serapan sari buah markisa sebelum dan sesudah melewati membran dilakukan dengan alat Spektrofotometer UV-Vis untuk melihat perbedaan pola spektrum serapan pada daerah UV-Vis. Larutan sari buah markisa sebelum dan sesudah melewati membran dipipet $2 \mathrm{~mL}$ diencerkan dalam labu ukur 10 $\mathrm{mL}$. Selanjutnya diukur serapan absorban pada daerah UV 200-400 nm.

\section{Penentuan Kadar Gula Reduksi dengan Metoda Luff Schoorl ${ }^{[7]}$}

Sebanyak $25 \mathrm{~mL}$ larutan Luff Schoorl diambil kemudian ditambah dengan $25 \mathrm{~mL}$ akuades (blanko). Setelah ditambah beberapa batu didih, erlenmeyer dihubungkan dengan pendingin balik, kemudian dididihkan. Pendidihan larutan dipertahankan selama 10 menit. Selanjutnya didinginkan dengan cepat dan ditambahkan $15 \mathrm{~mL} \mathrm{KI} 20 \%$ dan $\mathrm{H}_{2} \mathrm{SO}_{4}$ $25 \% 25 \mathrm{~mL}$ dengan hati-hati. Setelah itu dititrasi dengan larutan $\mathrm{Na}_{2} \mathrm{~S}_{2} \mathrm{O}_{3} \quad 0,1 \quad \mathrm{~N}$ sampai warna kuning gading, ditambahkan larutan kanji $1 \%$, dititrasi kembali sampai warna biru hilang. Lakukan hal yang sama untuk sari buah sebelum dan sesudah filtrasi, diambil sebanyak $20 \mathrm{~mL}$.

\section{Penentuan Kadar Vitamin C Pada Sari Buah Markisa}

Dipipet $10 \mathrm{~mL}$ sari buah markisa sebelum dan sesudah filtrasi kemudian dipindahkan ke labu $100 \mathrm{~mL}$ dan dilarutkan dengan akuades sampai $100 \mathrm{~mL}$. Diambil $20 \mathrm{~mL}$ larutan sari buah markisa yang diencerkan kemudian ditambahkan amilum $1 \% 2$ tetes. Larutan dititrasi dengan larutan standar $I_{2}$ sampai timbul warna biru ${ }^{[7]}$.

\section{HASIL DAN DISKUSI}

\section{Penentuan Fluks Akuades}

Fluks adalah jumlah volume permeat yang melewati satuan luas membran dalam waktu tertentu dengan adanya gaya dorong dalam hal ini berupa tekanan ${ }^{[3]}$ Pengukuran fluks ini diperoleh dengan mengukur volume akuades yang keluar tiap satuan waktu. Dari Gambar 1, dapat dilihat bahwa nilai fluks untuk masing-masing membran mengalami penurunan tiap waktunya setelah ultrafiltrasi. Penurunan nilai fluks disebabkan karena zat terlarut yang tertahan oleh filter lama kelamaan akan terakumulasi atau menumpuk pada permukaan membran dan mengakibatkan terbentuknya gel atau lapisan fouling pada permukaan membran, sehingga terjadinya pemampatan dan meningkatnya resistan (hambatan) pada permukaan membran $^{[4]}$. Dari nilai fluks akuades $(<50$ L/Jam $\mathrm{m}^{2}$ ) menunjukkan bahwa jenis filtrasinya adalah tipe ultrafiltrasi. 


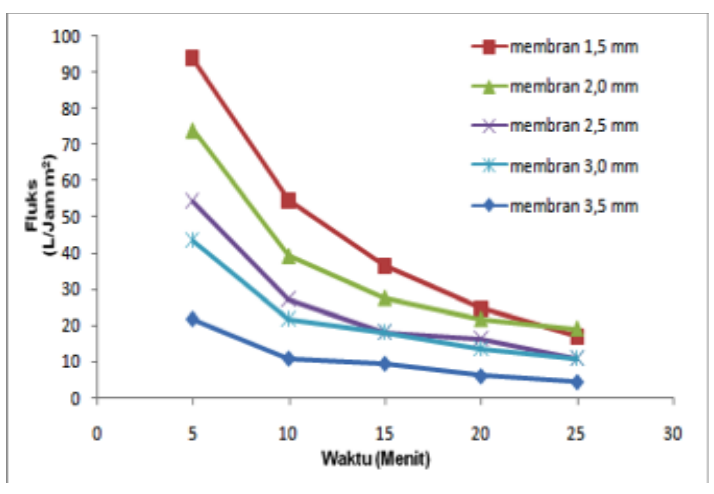

Gambar 1. Hubungan antara fluks akuades pada membran terhadap waktu.

\section{Penentuan Fluks Sari Buah Markisa Pada Membran}

Penentuan fluks dari sari buah markisa dilakukan seperti penentuan fluks akuades. Uji dilakukan pada membran yang tebalnya bervariasi, membran tebal 1,$5 ; 2 ; 2,5 \mathrm{~mm}$ yang dapat dilewati oleh sari buah markisa dan untuk membran tebal 3,0 dan $3,5 \mathrm{~mm}$ tidak mampu dilewati sari buah dikarenakan semakin tebal membran memungkinan terjadinya fouling lebih cepat di permukaan membran oleh partikel - partikel besar (suspensi) dari sari buah tersebut.

Gambar 2 menunjukkan semakin bertambahnya waktu nilai fluks mengalami penurunan pada setiap membrannya. Disebabkan zat pengotor yang semakin menumpuk pada permukaan membran membuat pori membran bertambah kecil yang membuat kinerja membran semakin berat dan menghasilkan penurunan jumlah volume permeat ${ }^{[3,5,8,9]}$.

\section{Pengukuran Spektrum UV-Vis Sari Buah Markisa}

Membran keramik digunakan untuk menjernihkan sari buah markisa maka dilakukan pengukuran terhadap warna. Dari hasil pengukuran spektrum, puncak sampel yang sebelum difiltrasi lebih tinggi dibanding sampel setelah melewati membran. Puncak maksimum dari sampel tersebut terletak pada $\lambda=237 \mathrm{~nm}$. Sari buah markisa yang telah dilakukan ulfiltrasi tersebut terjadi perubahan intensitas warna.

Dari Gambar 3. dapat disimpulkan bahwa sebelum dilakukan ultrafiltrasi menunjukkan nilai absorban yang jauh lebih besar dibandingkan setelah dilakukan ultrafiltrasi, hal ini disebabkan oleh konsentrasi zat warna sebelum diperlakukan lebih besar sehingga menghasilkan nilai absorban yang lebih besar.

Nilai absorban setelah dilakukan ultrafiltrasi menurun seiring bertambahnya ketebalan dari membran keramik yang digunakan. Penurunan nilai ini disebabkan oleh warna dari sari buah markisa telah tersaring oleh membran akibat diabsorbsi oleh partikel suspensi, dimana semakin tebal membran yang digunakan maka kemampuan membran untuk menyaring sari buah markisa juga semakin baik sehingga filtrat dari sari buah markisa semakin jernih. Oleh karena itu sari buah yang disaring oleh membran dengan ketebalan 2,5 mm mempunyai kemampuan yang paling bagus sehingga permeat sari buahnya lebih jernih.

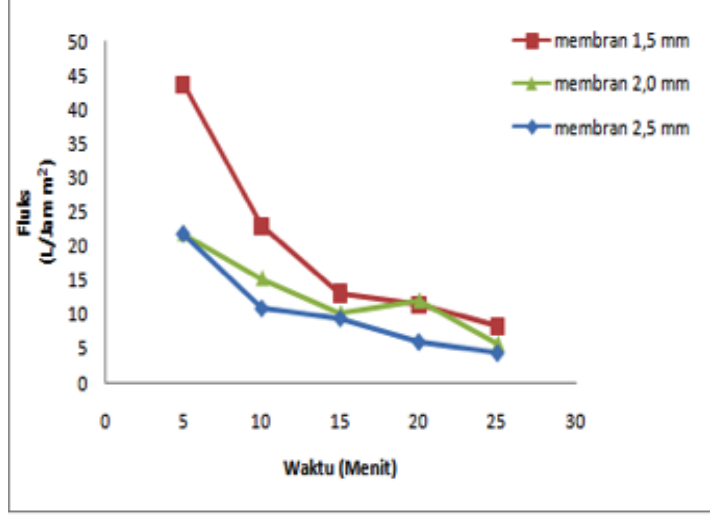

Gambar 2. Hubungan antara fluks sari buah pada membran terhadap waktu.

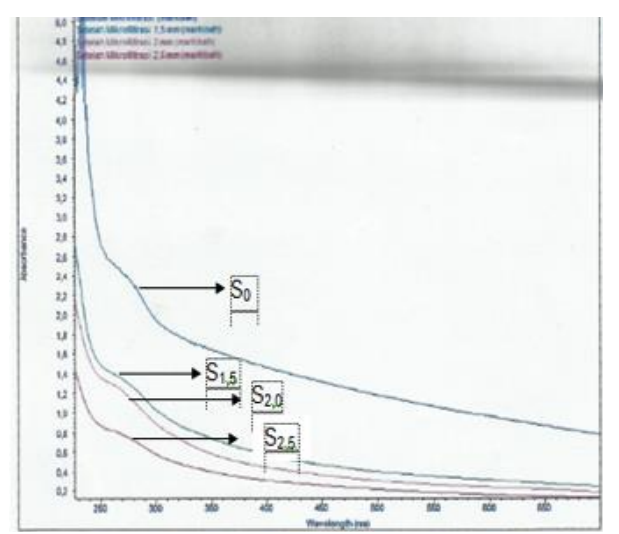

Gambar 3. Spektrum UV-Vis Sari Buah Markisa 


\section{Pengukuran Kekeruhan Sari Buah Markisa}

Pengukuran kekeruhan pada sari buah markisa ini dilakukan sebelum dan sesudah melewati membran dengan metoda turbidimetri, metode yang berdasarkan pada pengukuran intensitas cahaya yang ditransmisikan ${ }^{[10]}$. Dalam Tabel 1 nilai hasil pengukuran, nilai kekeruhan sebelum dan sesudah difiltrasi dapat dilihat bahwa nilai sebelum difiltrasi paling besar karena partikel yang tersuspensi banyak di dalam larutan. Hal ini membuktikan bahwa dengan proses ultrafiltrasi dapat mengurangi kekeruhan dari sari buah tersebut.

Nilai kekeruhan setelah filtrasi mengalami penurunan seiring dengan bertambahnya ketebalan membran. Hal ini mengindikasikan bahwa partikel yang tersuspensi di dalam larutan sari buah markisa terhalang di permukaan membran yang menyebabkan filtrat dari sari buah markisa jauh lebih jernih.

\section{Penentuan Kadar Gula}

Gula reduksi merupakan monosakarida dan beberapa disakarida yang mempunyai sifat mereduksi, sifat sebagai reduktor ini dapat digunakan untuk identifikasi karbohidrat maupun analisis kuantitatif. Dari Tabel 1 dapat dilihat tidak terjadinya perbedaan yang besar antara kadar gula sebelum dan sesudah ultrafiltrasi yaitu 22,8684; 22,6088; 22,1847dan 21,9078 \%. Dikarenakan ukuran molekul gula lebih kecil sehingga lolos (dapat melewati) pori membran keramik ultrafiltrasi.

\section{Penentuan Kadar Gula}

Gula reduksi merupakan monosakarida dan beberapa disakarida yang mempunyai sifat mereduksi, sifat sebagai reduktor ini dapat digunakan untuk identifikasi karbohidrat maupun analisis kuantitatif. Dari Tabel 1 dapat dilihat tidak terjadinya perbedaan yang besar antara kadar gula sebelum dan sesudah ultrafiltrasi yaitu 22,8684; 22,6088; 22,1847dan 21,9078 \%. Dikarenakan ukuran molekul gula lebih kecil sehingga lolos (dapat melewati) pori membran keramik ultrafiltrasi.
Tabel 1. Karakterisasi sifat fisika dan sifat kimia sari buah

\begin{tabular}{|c|c|c|c|c|}
\hline \multirow{3}{*}{ Sampel } & \multicolumn{4}{|c|}{ Parameter } \\
\cline { 2 - 5 } & $\begin{array}{c}\text { Warna } \\
(\mathrm{A})\end{array}$ & $\begin{array}{c}\text { Kekeruhan } \\
(\text { NTU) }\end{array}$ & $\begin{array}{c}\text { Kadar Gula } \\
\text { Reduksi (\%) }\end{array}$ & $\begin{array}{c}\text { Kadar Vitamin C } \\
(\text { mglmg) }\end{array}$ \\
\hline$S_{0}$ & 4,159 & 15,15 & 22,8684 & 0,00140 \\
\hline$S_{1,5}$ & 1,838 & 11,54 & 22,6088 & 0,00123 \\
\hline$S_{2}$ & 1,633 & 1,70 & 22,1847 & 0,00105 \\
\hline$S_{2,5}$ & 1,055 & 1,59 & 21,9078 & 0,00088 \\
\hline
\end{tabular}

\section{Penentuan Kadar Vitamin C}

Vitamin $\mathrm{C}$ tergolong vitamin yang mudah larut dalam air. Vitamin $\mathrm{C}$ atau asam Laskorbat adalah lakton, yaitu ester dalam asam hidroksi karboksilat dan diberi ciri oleh gugus enadiol yang menjadikan senyawa pereduksi yang kuat. Asam L-askorbat mudah teroksidasi secara reversibel menjadi asam L-dehidroaskorbat yang masih mempunyai keaktifan sebagai vitamin $\mathrm{C}$. vitamin $\mathrm{C}$ mudah teroksidasi dan proses tersebut dipercepat oleh panas, sinar, alkali, enzim, oksidator serta oleh katalis tembaga dan besi. Pada proses pengolahan pangan, kehilangan vitamin $\mathrm{C}$ akibat reaksi enzimatis jumlahnya sangat sedikit, sedangkan reaksi non enzimatis menjadi penyebab utama hilangnya vitamin $C^{[7]}$ Sama seperti kadar gula untuk vitamin $\mathrm{C}$ kandungan dalam sari buah markisa sebelum dan sesudah ultrafiltrasi tidak terdapat perbedaan yang signifikan yaitu 0,$00140 ; 0,00123 ; 0,00105$; $0,00088 \mathrm{mg} / \mathrm{mg}$, karena molekul vitamin C yang kecil juga dapat melewati pori membran keramik ultrafiltrasi.

\section{Nilai Koefisien Rejeksi Membran}

Koefisien rejeksi merupakan kemampuan suatu membran untuk merejeksi atau menghilangkan komponen-komponen yang tidak diinginkan seperti koloid atau makromolekul lainnya. Dari hasil tersebut dapat dilihat bahwa nilai koefisien rejeksi terhadap kekeruhan dan warna dari sari buah markisa memiliki nilai yang tinggi dibandingkan kadar gula, vitamin C. Hal ini disebabkan oleh kekeruhan sari buah disebabkan suspensi yang tertahan pada permukaan membran cukup besar dan warna juga ikut tertahan karena terabsorbsi oleh partikel suspensi, sedangkan molekul gula dan vitamin $\mathrm{C}$ lolos masuk ke dalam permeat, karena molekulnya yang kecil dari ukuran pori membran. 
Tabel 2. Tabel nilai koefisien rejeksi membran keramik

\begin{tabular}{|c|c|c|c|c|}
\hline & & & Rejeksi(\%) & \\
\hline Sampel & Wama & Kekeruhan & Kadar gula reduksi & Kadar Vitamin C \\
\hline$S_{1.5}$ & 55,8067 & 23,8284 & 1,1352 & 12,1429 \\
\hline $\mathrm{S}_{20}$ & 11,1534 & 85,2686 & 1,8758 & 14,6342 \\
\hline $\mathrm{S}_{25}$ & 35,3950 & 6,4706 & 1,2482 & 16,1905 \\
\hline
\end{tabular}

\section{KESIMPULAN}

Berdasarkan penelitian yang telah dilakukan dapat disimpulkan bahwa karakterisasi fluks akuades untuk membran $\mathrm{S}_{0} ; \mathrm{S}_{1,5} ; \mathrm{S}_{2,0} ; \mathrm{S}_{2,5} ; \mathrm{S}_{3,0}$ dan $S_{3,5}$ nilainya kecil dari $50 \mathrm{~L} / \mathrm{Jam} \mathrm{m}^{2}$, nilai ini menunjukkan membran keramik termasuk kategori ultrafiltrasi. Fluks sari buah markisa mengalami penurunan dengan bertambahnya waktu dan ketebalan dari membran. Nilai kekeruhan dari sari buah markisa untuk membran 1,$5 ; 2,0 ; 2,5 ; 3,0$ dan $3,5 \mathrm{~mm}$ adalah 15,$15 ; 11,54 ; 1,70 ; 1,59$ NTU, nilai kekeruhan dan warna berbanding terbalik dengan ketebalan membran. Penentuan nilai rejeksi membran terhadap kekeruhan dan warna diperoleh relatif besar, sedangkan kadar gula dan vitamin $\mathrm{C}$ relatif kecil. Oleh karena itu, ultrafiltrasi ini bagus digunakan untuk penjernihan pada sari buah yang dapat mempertahankan komposisi kimia dari sari buah tersebut.

\section{UCAPAN TERIMA KASIH}

Penulis mengucapkan terimakasih kepada analis Laboratorium Kimia Fisika Jurusan Kimia UNAND yang telah membantu selama ini.

\section{DAFTAR PUSTAKA}

1. Mulder.M, 1991, Basic Principles of Membrane Technoloy, Kluwer
Academic Publishers, London, pp. 281311.

2. Baker. R.W, 2000, Membrane Technology and Application, McRrawHil Companies, pp. 225-254.

3. Vladisavljevic. G. T. P, Permeate Flux and Fouling Resistance in Ultrafiltrtion of Depectinized Apple Juice Using Ceramic Membranes, Journal of Food Engineering, 2003, 60 (3), 241-247.

4. Noor, E., Adetiya R., Setyadjit, Model Perpindahan Massa Pada Pemekatan Sari Jeruk Siam dengan Reverse OsmosisTekanan Rendah, Jurnal Teknologi, 20(3),178-183.

5. Juansah, J., Kiagus D., Farida H., Peningkatan Mutu Sari Buah Nanas dengan Memanfaatkan Sistem Filtrasi Aliran Dead-end dari Membran Selulosa Asetat, 2009.

6. Maldini, Vicky.,Kajian Fisiologi Buah Markisa (Passiflora ligularis) dalam Penyimpanan pada Berbagai Tingkat Suhu, Skripsi Fakultas Teknologi Hasil Pertanian, UNAND: Padang2014

7. Dewi, K. S., F. Sinung P., Ekawati P.,Pengaruh Kombinasi Gula Pasir dan Sari Jambu Bui Merah (Psidium gujava linn.) Terhadap Kualitas Sirup yang Dihasilkan,Jurnal llmu dan Teknologi Pangan 2006. 4(1).

8. Agmalini, S., Narke N. L., Subriyer N., Peningkatan Kualitas Air Rawa Menggunakan Membran Keramik Berbahan Tanah Liat Alam dan Abu Terbang Batubara 2013. 2(19).

9. Lee, K. P., Mattia, D., Monolithic Nanoporous Alumina Membranes For Ultrafiltration Applications: Characterization, Selectivitypermeability Analysis and Fouling Studies, Journal of Membrane Science 2013, 435, 52-61.

10. Walimah, A., Turbidimetri Untuk Analisis Ion Sulfat dengan Menggunakan Flow Injection Analysis, 2013. 